\title{
Educational Leadership: Characterization of Emerging Practices
}

\author{
Mohamed El Wafiq ${ }^{1,2 *}$, Malika Tridane ${ }^{1,2}$, Said Belaaouad1 \\ ${ }^{1}$ Laboratory of Physical Chemistry of Materials, Faculty of Sciences Ben M'sik, Hassan II University of Casablanca, Casablanca, \\ Morroco \\ ${ }^{2}$ Regional Center for the Professions of Education and Training, Casablanca-Settat, CRMEF-CS, Maarif, Casablanca, \\ Morocco \\ Email: *m.elwafiq@gmail.com
}

How to cite this paper: El Wafiq, M., Tridane, M., \& Belaaouad, S. (2021). Educational Leadership: Characterization of Emerging Practices. Open Journal of Leadership, 10, 1-26.

https://doi.org/10.4236/oj1.2021.101001

Received: December 5, 2020

Accepted: January 26, 2021

Published: January 29, 2021

Copyright (c) 2021 by author(s) and Scientific Research Publishing Inc. This work is licensed under the Creative Commons Attribution International License (CC BY 4.0).

http://creativecommons.org/licenses/by/4.0/

\section{(cc) (i) Open Access}

\begin{abstract}
By following the evolution of situated practices and concepts of educational leadership, the transformation of the Regional Centers for the Professions of Education and Training in Morocco, from a local management mode to a regional management mode, has inspired us to characterize the new style of leadership practiced within these centers. For this, we took a sample of the Center of the Casablanca-Settat Region as a megalopolis. The eleven other centers in Morocco have the same institutional framework and the same regional operating logic. To collect data characterizing the leadership practiced in terms of building the center's commitments on a vision and values, we targeted the management and teachers, as the main actors of this leadership, through an online questionnaire. To validate certain information, we used the center's database. In terms of our work, we ended up with a form of leadership, which we called "satellite leadership", allowing each annex or provincial branch-of a Regional Centers for the Professions of Education and Training-to develop its local leadership while evolving with the changing orbit of regional leadership. This new configuration allows us to conclude on the possibility of carrying this style of educational leadership, at the national or international level, on any educational structure bringing together sub-structures grouped.
\end{abstract}

\section{Keywords}

Educational Leadership Practices, Trainer Center Manager, Teacher Trainer

\section{Introduction}

In a synthetic logic developed from the literature concerning the evolution of 
concepts and paradigms of educational leadership, on the one hand, and practices manifested in contexts referring to an institutional framework, on the other hand, we try to characterize educational leadership practices in a prototype representing training centers. This relates to the Regional Centers for the Professions of Education and Training in Morocco, known as CRMEF (Centres Régionaux des Métiers de l'Education et de la Formation). For us to be able to discuss the need to characterize a new leadership mode in these training institutions, we have provided an overview of the concentrated, distributed, systemic, integrated, and situated models of educational leadership; while being aware that we are part of a mapping of educational leadership practiced in emerging regions of Asia, Africa, and Latin America (Ribbins \& Gunter, 2002; Hallinger \& Bryant, 2013; Hallinger, 2014, 2018b, 2019; Hallinger \& Chen, 2015; Walker \& Hallinger, 2015; Flessa, Bramwell, Fernandez, \& Weinstein, 2017; Oplatka \& Arar 2017; Castillo \& Hallinger, 2018). Depending on the new managerial architecture of these centers, based on extended regionalization, it was necessary to compose their old modes of practiced leadership, with their expectations and challenges (Dutercq, Gather Thurler, \& Pelletier, 2015). Indeed, these centers have undergone significant changes since their creation in 2011 until today. Initially, these were centers, each headed by one director and with one school board where management and teachers are represented. With the extended regionalization in 2015, several Centers were grouped, following the new policy of regionalization of all sectors, in a single regional center, grouping several geographically distant centers, with a single Board of the establishment guarantor of the supervision of the good functioning of the center at the regional level. Faced with this new situation, we have set an objective proposing a prototype of educational leadership that takes into consideration local leaderships to develop a regional one that we have qualified as satellite leadership.

Based on the principle of reconstructing professional practices on new bases of cooperation and accountability (Pelletier, 2017), we have identified local leadership, particularly in terms of the construction of the center's commitments on a vision and values, which reflects the level of collaboration of the management and teachers of the entrance at the level of each annex or provincial branch. These must evolve within the leadership orbit of the center at the regional level. This satellite leadership, therefore, plays the role of regulator of the complementary efforts of the main actors, namely the management and the teachers, at the local and regional level, to achieve the objectives converging towards the continuous improvement of the performance of all the actors involved in the process. According to our context and in a logic of focusing on the practices of educational leadership, we rhyme with James \& Barry (2019), who characterizes leadership in higher education as practices that make the difference, and explain how people mobilize, in their establishments, the others so that they want to fight for common aspirations and make things happen. These, according to them, are the behaviors that leaders use to transform values into actions, vi- 
sions into realities, obstacles into innovations, subdivisions into solidarity, and risks into rewards. This transformation of values into actions can only be effectively considered through the initiation of changes aimed at improving the performance of all actors and in particular that of students (Hallinger, 2011a; Scheerens, 2012). This improvement has also been underlined by several researchers (Hallinger \& Heck, 1996; Witziers, Bosker, \& Kruger, 2003; Leithwood \& Mascall, 2008; Dumay, 2009; Bruggencate et al., 2012) who have followed various avenues to demonstrate its relationship with educational leadership. By evoking the dynamic that binds Management and Teachers in educational leadership, we cannot ignore the type of LMX (Leader-Member Exchange) relationship that regulates their involvement, as an internal or external group in the process of ameliorative change (Northouse, 2019).

This research was initiated under the influence of two motivations:

- The first is caused by the changing context in which administrative staff and teachers collaborate to create positive change. These changes mainly expect to improve the performance of students, without forgetting that of other actors by improving the conditions of their work. This context saw the regrouping and restructuring of several provincial establishments into a single regional establishment.

- The second is guided by the evolution of emerging practices, in terms of educational leadership, which tend towards an integrated style taking into consideration the natural emotional aspect of employees during the exercise of their professional activities. This evolution oscillates between a concentrated educational leadership and one distributed in a way situated according to the contexts.

Our work is carried out taking into account the evolution of concepts of educational leadership towards integrated leadership. The latter is practiced mainly by administrative staff and teachers. We used this same trend, except that we added the satellite aspect to it. This aspect proposes the development of local leadership for each local establishment. At the same time, these local leaderships are framed by regional leadership and evolve with its evolution.

\section{Theoretical Framework}

\subsection{Educational Leadership}

With the evolution of the concept of leadership, Collarbone \& Billingham (1998) succinctly marked the difference between leadership that provides vision, direction, and inspiration, and simple management that has to plan, monitor, and verify. In terms of educational leadership, since its inception it has always been seen as an interdisciplinary field in continuous interaction with other fields such as psychology-as long as it concerns individuals individually-and sociology-as long as it concerns the interaction between these people. Obviously, in this interaction, it is necessary to underline the interconnection of its branches when it comes to involving other actors such as teachers or directors. As the 
concept of educational leadership has evolved, some researchers have even noted that its field is subject to change. Regardless of the scope of these changes, the automated text-mining analysis of five decades of educational leadership research literature regarding probabilistic modeling of subjects of "Educational Administration Quarterly" articles from 1965 to 2014 administered by Wang, Bowers, \& Fikis (2017) showed the persistence of the subject of educational leadership. At the same time, Hallinger \& Kovačević (2019) have confirmed a paradigm shift from "school administration" to "school leadership" over the past six decades.

In summary lessons drawn from the Anglo-Saxon literature review, Piot \& Kelchtermans (2014) pointed out that the definition of educational leadership includes three elements present in most of the definitions found in the literature: leadership as influence, leadership, and values, as well as leadership and vision. Also, they see educational leadership as a concept that encompasses management and administration and refers to a process of social influence adopted by one or more members of the organization. Thus, it concerns all activities aimed at achieving the objectives of the organization and includes at least: the construction of a vision and objectives of this organization; the efforts to unite these members of this organization around this vision; the management or maintenance of existing organizational arrangements (Piot \& Kelchtermans, 2014) to achieve these objectives; and initiating changes to achieve these goals and therefore to improve the organization. This goes hand in hand with the spirit of continuous improvement of the Deming wheel, which is part of the logic of continuous improvement through planning, action, control, and regulation.

Not far from this approach, Dutercq, Gather Thurler, \& Pelletier (2015) also announces that educational leadership appears as a process of reciprocal influence, during which the members of a collective construct, interactively, the meaning of "acting together" which aims to transform teaching practices right down to the classroom. This transformation, which can only take place through the initiation of positive changes aimed at improving the situation of the establishment on the administrative and pedagogical level, must take into account the social and cultural context in which this establishment is located. While remaining open to the external environment of the establishment during the initiation of changes aimed at improving the performance of the establishment on all levels (Hallinger, 2011a, 2011b), we are aware that it is about exercising leadership that creates the climate in which people work together to turn difficult opportunities into remarkable successes (James \& Barry, 2019).

\subsection{Three Types of Leadership That Can Be Applied to Educational Leadership}

Over time, different models of educational leadership have been explored, including changing research trends on each model. The systematic review of studies of leadership models in educational research from 1980 to 2014, conducted by Gumus, Bellibas, Esen, \& Gumus (2018), is one example. Regardless of the type of actors involved in the educational leadership process, management, or 
teachers, this can be considered as a lever for improving the results and working conditions of all actors with no mutual benefit: it is transformational leadership. The second point that of meeting and exchanging of interests such as transactional leadership which is destabilized according to the variations of these stakeholders: it is transactional leadership. Finally, and not exclusively, the management or the role-play between teachers and management to bring improvements to the establishment can be left to circumstances: it is a question of leadership of the "laissez-faire" or "let go type" while waiting for things to regulate automatically.

\section{1) Transformational leadership}

In some studies, some authors, such as Garant, Letor, \& Bonami (2010) have stated that learning organizations are led by managers who exhibit characteristics of "transformational leadership". These studies have shown the impact of transformational leadership on satisfaction increase, engagement, and effectiveness in some organizations.

Among the transformational leaders of these organizations, we can observe (Garant, Letor, \& Bonami, 2010): a capacity to rally through vision, to transmit this vision and to build a shared interpretation; an ability to listen to interlocutors, to recognize people and teams and to gain the trust of collaborators support for the development of creativity, investigation and controlled experience; personal development based on a positive self-image as well as a positive image of the other; and attention to the individualized professional development of the learning capacities of each collaborator.

It should also be noted that several studies, for example, those by Hooper \& Bernhardt (2016) have established links between transformational leadership and the feeling of effectiveness and satisfaction of teachers. For this type of leadership, the development of learning communities is facilitated by modeling and norms strengthening that create trust, respect, collegiality, and ethics, in a climate of safety and benevolence.

For further specification, we can cite the precision of Tintoré (2019) who subdivides transformational leadership into two categories: charismatic transformational leadership and pro-social transformational leadership. Both styles of transformational leadership share a desire to go beyond the leader's aspirations to collectively try to transform others. Indeed, followers of the pro-social transformational style are more focused on organizational mission and collaboration, while followers of the charismatic transformational style are focused on achieving their goals. However, the charismatic transformational leader can be much more individualistic, while the pro-social transformational leader aims to promote followers into leaders (Rey \& Cardona, 2015). To take this systemic and social logic further, Miller (2019) proposes leadership for social justice that takes into consideration the material, economic and social differences between different groups and focuses on the creation of opportunities based on fairness for all. 


\section{2) Transactional leadership}

According to Burns (1978), who was the first to characterize this type of leadership, transactional leaders motivate their subordinates by providing them with rewards that directly serve their interests, in exchange for the work done. For him, transactional leadership is based on a legitimate power given to the leader within a bureaucratic structure of the organization. This type of leadership involves a negotiated exchange of interest between leaders and subordinates.

Unlike the transformational leader, the transactional leader announces the pre-set objectives of the organization and deploys all the means of a transaction so that the subordinates adhere to them. Even though this type of management is based on the exchange of interests, employees know very well what to do and what is expected of them in a pseudo-logic of rights and obligations. Although this type of management seems pragmatic and operational in the short term, effectiveness and efficiency are not neglected. In the context of a higher education establishment, such rules of games and compromises cannot be established, given the balances of power practices across the different structures such as the establishment council and the different commissions, without ignoring the presence of the union body.

\section{3) "Laissez-faire" leadership}

This type of leadership is characterized by Bass (1998) as being the absence of transactions with subordinates. For example, leaders of this type of leadership (Hoy \& Miskel, 2012) avoid expressing their views or taking action on important issues, hesitate to make or at least delay decisions, ignore responsibilities, provide no feedback and let go of authority in an idle state. It is essentially, according to these authors, the absence of leadership, and therefore, it is the most passive and the least effective. An example would be a principal who stays in the office, engages teachers and students as little as possible, shows minimal concern for student learning and development or the needs of teachers, and allows school structures and processes to continue to function in the same way. No proactive or planned planning and no positive or projected change trigger. This is a reactive management method.

\subsection{Evolution of the Concept and Paradigm of Educational Leadership}

Assuming that educational leadership is an applied field (Campbell, 1981; Riffel, 1986; Rowan, 1995), the complexity of the contexts leads, according to the paradigm to learn to practice and to practice to learn, to an evolution of the forms of concepts oscillating between the concentrated educational leadership and the distributed educational leadership, according to the circumstances, on actors such as the direction and the teachers. This development, in its systemic approach which takes into consideration the needs and expectations of all actors, tends towards an integrated model that naturally takes into account the emotional aspect of these actors during the exercise of their professional activities. 


\section{1) Educational leadership: a concentrated or a distributed process?}

The focused or distributed aspect of educational leadership is ubiquitous, whether transactional or transformational. Indeed, for a long time, the consideration of the plural aspect of educational leadership has gained space and time. For example, Yukl (2006) asserts that the leadership actions of any individual leader are less important than the collective leadership provided by members of the leadership because the power and influence of an organization are spread over several people and several processes (Gronn \& Hamilton, 2004). This, however, is often overlooked by focused approaches that grant the opportunity to influence others to those in official managerial positions, something which is becoming increasingly incompatible with the growing complexity of organizations which requires an effort of coordination and considerable and permanent consultation. The case of the extension of the last regionalization of the Regional Centers for the Professions of Education and Training in Morocco, with the new occupations of the positions of deputy directors and directors in charge, is a concrete example. The development of remote communication and collaboration means, given the geographical distribution of the sites of these centers, only consolidates this thesis of distributed leadership. Beyond this comparison and by mentioning Vuori's (2019) statement which states that distributed leadership is mainly practiced in higher education institutions while recalling that it is also found in other contexts, Harris (2004) challenges us that distributed forms of leadership can contribute to the improvement of the school.

In the context of the regrouping of distant training establishments and the need to strengthen the supervision of their proper functioning, through shared leadership between management and teachers, we evoke the position of Hargreaves \& Fullan (2012) which indicates that taking into account directors the distributed dimension of leadership can be a driver of professionalization. However, this growing professionalism-of the professions of teachers and directors, which aims to enhance, develop and put at the service of the collective good the skills identified by the two main actors-are experiencing shortcomings and deficiencies in terms of design and deployment of initial and continuing training in training systems. Indeed, the qualification of directors provides for training modules dealing with educational leadership and emphasizes its importance as a lever for improving the performance of educational establishments. At the same time, few, if at all, training takes into consideration the qualification of teachers in terms of distributed educational leadership (Perrenoud \& Progin, 2018).

We note that during a trend towards a focus on distributed leadership, one must take into consideration, according to some authors such as Zulkifly, Ismail, \& Asimiran (2020), its differentiation from collegial leadership. Indeed, they characterize collegial leadership-as opposed to distributed leadership-in that decision-making is consensual and power is shared with other employees.

2) Trained as potential actors in educational leadership

If we consider, on the one hand, Greenfield (1991) who conceives of educa- 
tional leadership as an organizational construct that concerns officials as well as other members of the school staff, and Dutercq, Gather Thurler, \& Pelletier (2015) who confirm that it can be exercised by any person who assumes, officially or in fact, a position of responsibility and practices within training institutions. On the other hand, educational leadership can also be shared with students having significant experience and maturity, especially in the context of adult education. Indeed, among future teachers, some have already worked in the private sector, teaching or otherwise, up to the regulatory age of forty-five in the case of Morocco. As for future administrative managers, they already have teaching experience and there are even those who have some administrative experience on the job. Added to this is the fact that they have formal representativeness on the school board supported by the laws in force. Since the Center council, commonly appointed by the Institution's council, has the role of supervising the proper functioning of the center, the students, being part of this council, can also bring added value by expressing and defending the interests of colleagues in their respective categories. Something that is found in Moroccan higher education in general, but which is not considered in school education.

From this observation was born the idea of characterizing the leadership practices in an adult training center such as a CRMEF, taking into account the contribution of students. Since our study is limited to a leadership shared mainly between the school administration and the teacher trainers, we focus our study only on this type of leadership.

3) Towards a conceptual framework for systemic, integrated, and hybrid leadership

Given that we cannot evoke educational leadership, in a systemic approach, without primarily targeting its positive impact on student performance, Hallinger \& Heck (2010) confirm that distributed leadership can, on the one hand, exert a direct influence on the evolution and improvement of practices within educational institutions and, on the other hand, have an indirect influence on the level of learning of students. This can be supported by the words of Young, Winn, \& Reedy (2017) who highlight the important role that school leadership plays in supporting the results of students, teachers, and the whole school. As for the Bruggencate, Luyten, Scheerens, \& Sleegers (2012), they refer in particular to the influence of principals on the results of students and to what extent they can make a difference. As an output of this system, the performance of students must be perceived, in its integrated dimension, jointly taking into account the improvement of their living conditions and their learning.

In the same systemic logic, authors like Hallinger (2011a), underline the need to adapt leadership practices to the local characteristics of the educational institution and highlight the significant presence of processes of mutual influence between management and teachers. This awareness of the local characteristics of the establishment, which is an integral part of its culture, must also take into account the economic, social, and partnership environment that surrounds it. In 
this sense, authors such as Clarke \& O'Donoghue (2017) have shown how sensitive the establishment is to its context. Context to be brought out, according to Hallinger (2018a), from the shadow of leadership.

In its hybrid approach, or concentrated and distributed depending on the circumstances, leadership can be located. Gronn (2008), who once championed the distributed approach to leadership, pointed out that it would be better to limit the distributed term to actions carried out jointly by management and teachers. Individually, management or teachers can initiate and carry out designated educational leadership actions; and this leadership is not exclusively reserved for moments of sharing.

In the face of this evolution of educational leadership concepts and practices, we take up the words of James \& Barry (2019) in which they realize that leadership development is ultimately self-development. And that meeting the leadership challenge is a personal-and daily_challenge for everyone.

\section{Institutional Framework}

In this context, we present an interpretation of the laws, decrees, orders, and regulations in force that govern the context of work and operation of the Regional Centers for the Professions of Education and Training. These regulations were initiated, negotiated, and validated within the council of the center. In this council, where management and teachers are represented as the main players in educational leadership, decisions concerning the proper functioning of the center are drawn up and validated. From this presentation and reading in the regulations, we expect to perceive its systemic and integrated approach which takes into consideration the interests and needs of all the actors of the Center, namely, the Management represented by the Director and the Deputy Directors; teachers; Administrative Staff and Technicians; and the Students. The efforts of all these actors, who are represented on the school board, should in principle converge towards the continuous improvement of the performance of the Center on all levels and mainly at the level of improving student's performance.

\subsection{Identification and Areas of the Center's Activity}

The Regional Center for the Professions of Education and Training of the Casablanca-Settat Region is part of a national network made up of twelve similar centers spread across all regions of Morocco. It is considered to be a training establishment for senior executives under the supervision of the government authority responsible for national education in Morocco. It provides basic and continuing training and participates in the development of educational research.

In the area of basic training, the Center ensures the qualification of faculty executives for preschool, primary and secondary education; preparation of candidates for secondary education aggregation exams; and the training of pedagogical administration officials and administrative, educational, and social support staff. 
In the area of continuing education, the Center organizes continuing education cycles for different categories of ministry staff, including administrative, educational and social support executives; and educational administration officials, to modernize and develop their knowledge, skills, and professional experience. Another training relates to preparing them for entrance exams and professional qualification examinations.

In the field of scientific research in education, the Center carries out applied research activities in the fields of pedagogy, didactic, and the governance of education and training establishments. It is also called upon to propose projects of reform and renewal of curricula and training programs, as well as projects of partnership and cooperation agreements in the field of training with national or international public and private bodies and institutions.

\subsection{The Managerial Functions of the Direction's Center}

The Center is managed by a Director, Deputy Directors, and a Secretary-General. The Director is responsible for managing the Center, coordinating all its activities, and chairing its board, determining its agenda, following the conditions set out in its regulations. The center director is also in charge of managing all categories of staff assigned to the Center; ensuring the proper conduct of studies and control of information by taking all necessary measures for this purpose; negotiating cooperation agreements submitted to the Board of the Center for approval, and ensuring compliance with the laws and regulations in force and the internal regulations within the Center and can take all measures according to the circumstances. It should be noted that these acts are framed by Article 34 of Law 01.00 on the organization of Moroccan higher education. This article specifies the role of the Management of the Center as manager and guarantor of its proper functioning.

The Director is assisted by four Deputy Directors and a Secretary-General. The first director is responsible for the qualification cycle of the teaching staff; the second is responsible for the preparation cycle for the aggregation entrance exam; the third is responsible for the training cycle for pedagogical administration executives and executives of the administrative, pedagogical and social support body; and the fourth is responsible for continuing education and scientific-educational research, both theoretical and practical. These Deputy Directors are responsible, under the supervision of the Director of the Center, for the organization and implementation of educational activities; preparation and implementation and coordination of practicum and applied training programs; the preparation, monitoring, coordination, and implementation of scientific research activities in education; the organization of meetings, seminars, and training seminars scheduled within the framework of the activities of the Center; and the coordination of the activities of the provincial branches, if they are any.

The Secretary-General is responsible for the administrative management of the Center through the secretariat missions of the Council of the Center, in- 
cluding the conservation of the minutes and their availability to all the members of the Council. These missions should in principle be used for the establishment and development of knowledge management which capitalizes on the accumulated experiences and good practices of the Council of the Center. Since the mandate of this Board changes every four years, its new members, benefiting from this knowledge management, are expected to take over and ensure the continuity and development of its work.

\subsection{The Council as Supervisor of the Proper Functioning of the Center}

According to the laws in force, the Center Board must be composed of ex officio members, namely the Director of the Center, as Chairman of the Board, and the Deputy Directors; Heads of Departments; and members elected from among the teaching, administrative and technical staff, and student interns from the three training cycles.

The Council of the Center must perform the functions mentioned in article 35 of Law No. 01.00 on the organization of higher education in Morocco. This article stipulates that the School Board considers all questions relating to the missions and the proper functioning of the institution. On this, it proposes projects for the creation of training and research sectors; It draws up the regulations for examinations and knowledge checks of the training courses provided; It ensures the distribution of resources between the different structures; It exercises disciplinary power over students under the conditions determined by the governmental supervisory authority; it draws up its internal regulations; it creates standing committees within it, including a scientific committee and a budget monitoring committee and, where applicable, ad hoc committees. The number, composition, and operating procedures of the standing committees are set out in the institution's internal regulations.

This presentation of nature and the composition of the Council of the Center shows its plural aspect of distribution of roles and powers allowing to exert multiple and mutual influences on the part of all the actors and mainly the teachers with their high rate representativeness within the Council of the Center, and management with its permanent presence in all administrative structures. This would make it possible to establish and promote a leadership model aimed at improving the working conditions and the performance of the Center at the administrative and educational level.

\subsection{The Scientific Commission and Its Impact on the Involvement of Researchers}

In each Center, a Scientific Commission is made up jointly of research professors elected by their colleagues and of the Director of the Center as president of this commission. Its main mission is to propose all measures relating to the tenure and promotion of professor-researchers. At the same time, it participates in 
the various scientific events organized by the Center. Given its direct impact on the promotion of teacher-researchers, rules of power play, participation, and involvement of its members are set and a model of transactional leadership can easily be established.

\section{Research Objective}

Characterize the new style of leadership practiced within the Regional Centers for Education and Training Trades in Morocco, and propose an educational leadership model adaptable to training establishments with a similar operating administrative structure.

\section{Methodology}

To address the characterization of the leadership style practiced within the Regional Centers for Trades of Education and Training, we took as a sample the Center of the Casablanca-Settat Region as a megalopolis. The eleven other centers in Morocco have the same institutional framework and the same regional operating logic. We collected data characterizing the leadership practiced in terms of building the center's commitments to a vision and values. We targeted management and teachers, as the main players in this leadership, through an online questionnaire for a sufficiently representative population (37.83\%) of its teachers. Taking advantage of our proximity, to complete and consolidate our information from the data received, we have recourse to real data saved on the database of the Centre's information system. It should also be noted that to achieve an acceptable level in terms of the number of respondents, we have gradually used online forms, e-mails, and direct telephone calls.

\section{Results}

\subsection{The Sample Representing the Management of the Center}

Given the small number of Directors and Deputy Directors and the importance of any Director in the leadership process locally or regionally, it was necessary to contact all Directors of the Annexes, Provincial Branches, and Headquarter. These Directors, shows, have a balanced academic and professional profile. Five out of seven have an academic doctorate level and all have professional training in teaching. As for the managerial profile, senior positions, of Directors of Regional Centers, Deans of Faculties, Directors of Engineering Schools, or even of Moroccan University Presidents do not require prior specialized training in management. The same logic applies to Deputy Directors. The number of years of teaching experience for Directors at CRMEF is between 7 and 25 years, with an average approaching 15 years. To exercise the profession of Director or Deputy Director, no prior experience is required. Only the job interview is decisive in selecting the Directors. This gives more chances and dynamism to the renewal of posts based on-field skills. The number of years of experience in the exercise of the profession of Director testifies to this thesis. According to the data availa- 
ble on the number of years of practice of the profession of Director in a CRMEF at the national level, the trend also confirms this thesis.

\subsection{The Sample Representing the Teachers of the Center}

Given that the number of teachers is relatively large, about teaching and research activities, and their geographical dispersions on remote places and towns, we have collected, after several attempts of direct and indirect contacts, $37.83 \%$ of responses with a confidence level of $90 \%$ and a margin of error of $7 \%$. This is a reasonable percentage allowing us to get an idea of the state of play in terms of the components of leadership practiced by teachers. It should also be noted that the respondents were distributed in a balanced fashion across headquarters, provincial branches, and annexes. A very specific case was noted at the level of the provincial branch of Ben Slimane where we received no response during the transitional period of departure of its director. These teachers have a level of training that goes hand in hand with the academic and professional qualification of the CRMEF which has been triggered since 2011. This explains the large number of teachers with a Doctorate or a Ph.D. However, the number of teachers with a BA/BSc, a Masters or equivalent, can be explained by the inclusion of new project managers and former teachers of the Regional Pedagogical Center system. In the same way as for Directors, the academic and professional diplomas (Teacher Training Center, Regional Pedagogical Center, Higher Normal School, Higher Normal School for Technical Education, Aggregation and University accreditation) of teachers testify to a dual competence in specialties and educational sciences; what is desirable and necessary for the proper exercise of their profession. The fluctuations in the number of years of teaching experience of teachers are, at an average of 23.85 years, with a standard deviation of 9.03. This shows considerable seniority whose skills are to be valued and capitalized, and others are to be updated. The seniority of teachers, in teaching, in the CRMEF, tends to an average of 10.63 years, with a standard deviation of 8.69. This is due, despite the high average tenure of teachers in teaching, to the fact that a large number of former teachers is influenced by the large number of new teachers newly assigned on a probationary period. The choice of recruiting new assistant professors triggered since the start of the qualification of the CRMEF is declining in favor of the professors in charge of mission according to academic and professional criteria simultaneously taking into consideration the degrees and professional experience in teaching.

\subsection{Representativeness of Management and Teachers on the Centre's Council}

Since the Director and Deputy Directors are ex officio members of the School Board, commonly called the Center Board, it is important to see the response rate of teachers who are members of this Board compared to other teachers who are not members. Thus, $20.69 \%$ of the responding teachers were identified as 
members of the Council of the Center. Returning to the Centre's database, we found that these responding teachers constitute $58 \%$ of the teachers on the Board. This should impact the close nature of the responses about the missions and the current functioning of the said Council. There is nothing to prevent other teachers who are not members of the Center Council from being removed from its entrants and exits, especially those who were previously very active representatives, so their answers are very useful. On the other hand, we can find teachers who are members of the Council of the Center and are not sufficiently involved in its missions and commissions. Their influence on the leadership process remains very limited.

In all cases, and apart from the number of responding teachers who are members of the Center Council, called the School Council, it should be noted that the number of teachers who are members of this Council-respondents and non-respondents-represents, $76 \%$ of the total number of representatives of the Center in the Board of the Establishment. This constitutes an opportunity for teachers to have a significant degree of influence on decisions concerning the supervision of the functioning of the Center, in general, and on the process of its educational leadership at the regional level, in particular.

After the presentation of the target audience of our survey, in this case, the Management and the Teachers, as the main actors of leadership, while recalling that they are also the main actors of the Board of the establishment as a guarantor of the proper functioning of the Center, we begin the main and fundamental axis of any educational leadership and which constitutes the essence of our publication. It is about building the Centre's commitments on vision and values.

\subsection{Construction of the Centre's Commitments on a Vision and Values}

If we start from the principle that educational leadership is first and foremost management encompassing organizational management arrangements, it is the triggering of changes aimed at the continuous improvement of the organization according to its objectives and vision, which reflects its values, which qualifies it as leadership. In this process, we will focus particularly on the issue of sharing a common vision between the main actors of educational leadership, namely management, and teachers, then we try to recognize the essential values that can be shared between them.

\section{1) The Center vision}

On the question of the Centre's vision, one Director in seven and $17.44 \%$ of the responding teachers explicitly state, that the Center does not have a written document specifying the institution's vision. At the same time, $50.00 \%$ of the responding teachers say they do not know whether the Center has a written document specifying the school's vision or not. In return, six directors out of seven and $32.56 \%$ of the responding teachers explicitly state that the Center has a written document specifying the institution's vision. Faced with this confusion 
and after direct verification with the respondents, it turned out that the Center does not have a written document specifying the vision of the establishment and that there was confusion between the vision of the establishment, in a general way-about its mission and its reason of being - and a written vision, specific to the Center of the Casablanca-Settat Region which distinguishes it from other Centers and which constitutes its compass of direction. Out of curiosity, and after investigation, we learned that none of the twelve centers nationwide has its own written vision. This prompts the question about the improvement of any educational leadership characterized by its practices.

In any case, the construction of the Centre's commitments on a vision and values should translate the mission of the Center in terms of present commitments, based on values, allowing this future vision to be achieved. Directors and teachers, as the main actors in the process of educational leadership, believe in the importance of having a vision for a Center. However, it is necessary to differentiate between the individual vision of each Director or each teacher-which can refer to individual representations-and a common vision written and developed collaboratively. It is this last vision which would distinguish each Center from the other Regional Centers and which should, of course, not be contradictory neither with the strategic vision of the 2015-2030 reform of Morocco declared for a school of equity, of quality, and promotion nor with the program of his ministry of education.

\section{2) Practices characterizing values}

\section{- The Centre's project?}

As to the question of the Center project, two Directors out of the total of the seven Directors stated that the Center does not have any project other than the project of the Director of the Center. Either they think that the Center does not have a project at all, or they think that the Centre's project is the same as that of the Director of the Center. The other Directors (five out of seven) announced that the Center did have a different project from that of the Director. As for teachers, only $27.71 \%$ of respondents say that the Center does have a project other than that of the Director of the Center. $56.63 \%$ of the respondents have no idea on this question (among these teachers, 6 are members of the Council of the Center) and $15.66 \%$ affirm that the Center does not have a project different from that of the Director, either the same as that of the Director of the Center.

Among the Directors who confirmed that the Center has a vision and a project of the Center, other than the project of the Director of the Center, one Director did not speak out on this issue. Only two directors out of seven think that the Centre's project contributes perfectly to the realization of this vision. Among the teachers who confirmed that the Center has a vision and a project of the Center, other than the project of the Director of the Center, $66.6 \%$ think that the project of the Center contributes somewhat or perfectly to the realization of this vision. Officially, there is no vision of the Center developed according to the participatory approach to total quality management. Also, by asking this ques- 
tion directly to a few teachers who responded favorably for the existence of this vision, we found that it is a representation of a vision and not of a written and displayed vision. And it is this display that helps to make it known and shareable.

In any case, as to the Centre's project-which differs from that presented by the Director to apply for his post-as well as his vision, confusion is noted on the part of Directors and teachers. Two Directors state that the Center does not have a Center project, while the majority of the responding teachers state that the Center does not have this type of project or have no idea about it. However, such a project must constitute a common ground for focusing energies and work to achieve the expected objectives and enable the annual performance of the Center to be measured. Which would support the realization of his vision. Beyond any confusion, it should be noted the triggering of awareness of the importance of the existence of a common program linked to a shared vision.

\section{- Supervision of the Centre's missions by its Council}

Five out of seven Directors say that the Center Board often, if not always, oversee the Centre's missions, while the remaining two say they are occasionally supervised. This perhaps comes down to the management method adopted by the Center at the annex or provincial level, which is predominantly non-implicative or non-participatory. In any case, article 34 of Law 01.00 on the organization of Moroccan higher education, specifies the role of the Management of the Center as manager and guarantor of its proper functioning, but also indicates, in article 35 of the same law, that the Council supervises the missions of the Center and its proper functioning. This guarantees a complementarity of the roles of the Management and the Council and a normal continuity of the functioning of the Center in the event of failure of its Council, a majority of teachers (70.13\%) think that the Council of the Center often supervises, if not always, the missions of the Center and its good functioning. This gives an image of management with a participatory nature, to nearly $27.27 \%$ who say "sometimes". This observation makes it possible to announce relatively a mode of leadership shared between management and teachers within the CRMEF of the Casablanca-Settat region.

- Decision-making regarding the management of the Center at the regional and local level

The statements of the Director and the Deputy Directors show, that decisions concerning the management of the Center at the regional level are taken, in a situated manner, by the Director in coordination with the Deputy Directors, by the Director alone, or by the Deputy Directors individually. This confirms, on the one hand, the decisive role of the Director in certain situations where his sole responsibility is in great demand for the maintenance of the normal functioning of the Center; and the informal delegation of decision-making given to Deputy Directors to locally unblock regional situations, on the other hand. At the local level, decisions concerning the management of the Center at the local level are often taken by the Director. This prompts reflection on the role of Deputy Directors at the level of local management of their annexes or provincial branches. 
Indeed, until today, in an era of extensive regionalization, the Director of the Center is always called upon to resolve local situations that are part of the tasks and missions of the Deputy Directors. The normal situation presupposes an effective and permanent involvement of local officials in the management of local affairs.

\section{- Good practices}

According to the declaration of $35.71 \%$ of teachers, at the regional or local level, the Direction encourages actors enough to put in place good practices, while $48.81 \%$ consider that it is, in fact, a common practice. This constitutes a percentage of $84.52 \%$ of teachers who believe that Management encourages all actors to put in place good practices. This converges, in part, towards the construction of the Centre's commitments, through the Management, on a perceived vision and values.

It should also be noted that the overwhelming majority of teachers consider that the Management takes sufficient account of the needs and expectations of students, teachers, and administrators, otherwise it considers this to be standard practice.

According to the teachers, in the event of problems at the regional or local level, they are recognized, declared, and dealt with by involving all the parties concerned. Then, arrangements are sought within the framework of the law, otherwise, the regulations in force are applied after the failure of the arrangements. This behavior is sufficiently observed or described, as a common practice.

\section{- Taking into account the emotional aspect during professional activities}

According to Piot and Kelchterman (2014), the emotional dimension cannot be separated from any process of educational leadership. This prompted us to find out how far management and teachers show their emotions during the exercise of their profession. Quite simply, Directors do not hesitate to say that they show their emotions during the exercise of their professional activities. None of them denied expressing their feelings during their work. On the contrary, two in seven say that they show them often and five in seven say that it is casual behavior. This tends towards a recognition of the inevitable emotional dimension which is a natural part of the personality of the Director that it is enough to consider it instead of oppressing it to appear professional. It's the same coin with two inseparable sides. As for teachers, the majority (51.76\% sometimes, $30.59 \%$ often and $8.24 \%$ always) recognize the expression of their emotions during their professional activities, with the only difference that $9.41 \%$ declare that they never show their emotions during their work. Which puts them in an unnatural situation. From this observation, we cannot deny the taking into account of the emotional dimension in any process of leadership putting in common joint actions of the Direction and the teachers.

\section{- Development of educational and citizen partnerships}

Regarding the essential question of building the Centre's commitments on a vision and values, the Center, according to six Directors and $66.67 \%$ of teachers, 
is moving towards the development of educational and citizen partnerships. Which is not negligible. While $27.59 \%$ of teachers say they have no idea about these partnerships. Among these teachers, four are members of the Council of the Center who should be aware of them as soon as these agreements must pass through the Council of the Center for approval. At this point, it is necessary to note the assumption of a real, effective and active involvement of all the members of the Council of the Center as a structure of supervision of the good functioning of the Center. Only 5.75\% of the responding teachers think that the Center is not oriented towards the development of educational and citizen partnerships. This is a very small, but very important percentage to consider for future improvements that are part of any shared leadership.

\section{Discussion and Perspectives}

The current context of extensive regionalization of the CRMEF in the Casablanca-Settat Region is the same as that of all the CRMEFs in Morocco. Indeed, the repository of the operating logic of its management and its Board of establishment is derived from the same laws and regulations. Before the extensive regionalization of these CRMEFs, each branch or provincial branch of a CRMEF was headed by its Director and had its own Institutional Council; each of these councils brought together management and teachers. Since the extended regionalization in 2015, the Regional Center has been directed by a single Regional Director, assisted by Deputy Directors of the annexes and provincial branches of the same CRMEF, and has a single Board of the establishment, which guarantees the proper functioning of the Center. To capitalize on the Knowledge management of the headquarters, annexes, and provincial branches, which were once independent centers, the current practices of the Management (Regional Director and Deputy Directors) and teachers, about the shared educational leadership of a systemic and integrated way, testify to the coexistence of local educational leadership with regional educational leadership. So that there is no overflow of the two types of leadership, the Council of the Regional Center-which brings together regional representatives from the Direction and teachers from all over the region-is the appropriate structure to coordinate the individual driving forces headquarters, annexes, and provincial branches. The Regional Center is therefore a logical structure endowed with its regional driving force bringing together physical structures represented by the head office, the annexes, and the provincial branches. Each of these physical structures having to evolve within the orbit of the regional logical structure which encompasses, frames, and guides the Centre's satellite educational leadership at the regional level.

As a summary drawn from this investigative work, we note that this configuration of this type of educational leadership can be viewed (see Figure 1) as a portable model. Indeed, given that all higher education institutions in Morocco, whether or not belonging to the university and which are grouped, according to logic, under the roof of a Council-taking into account the level of complexity of 


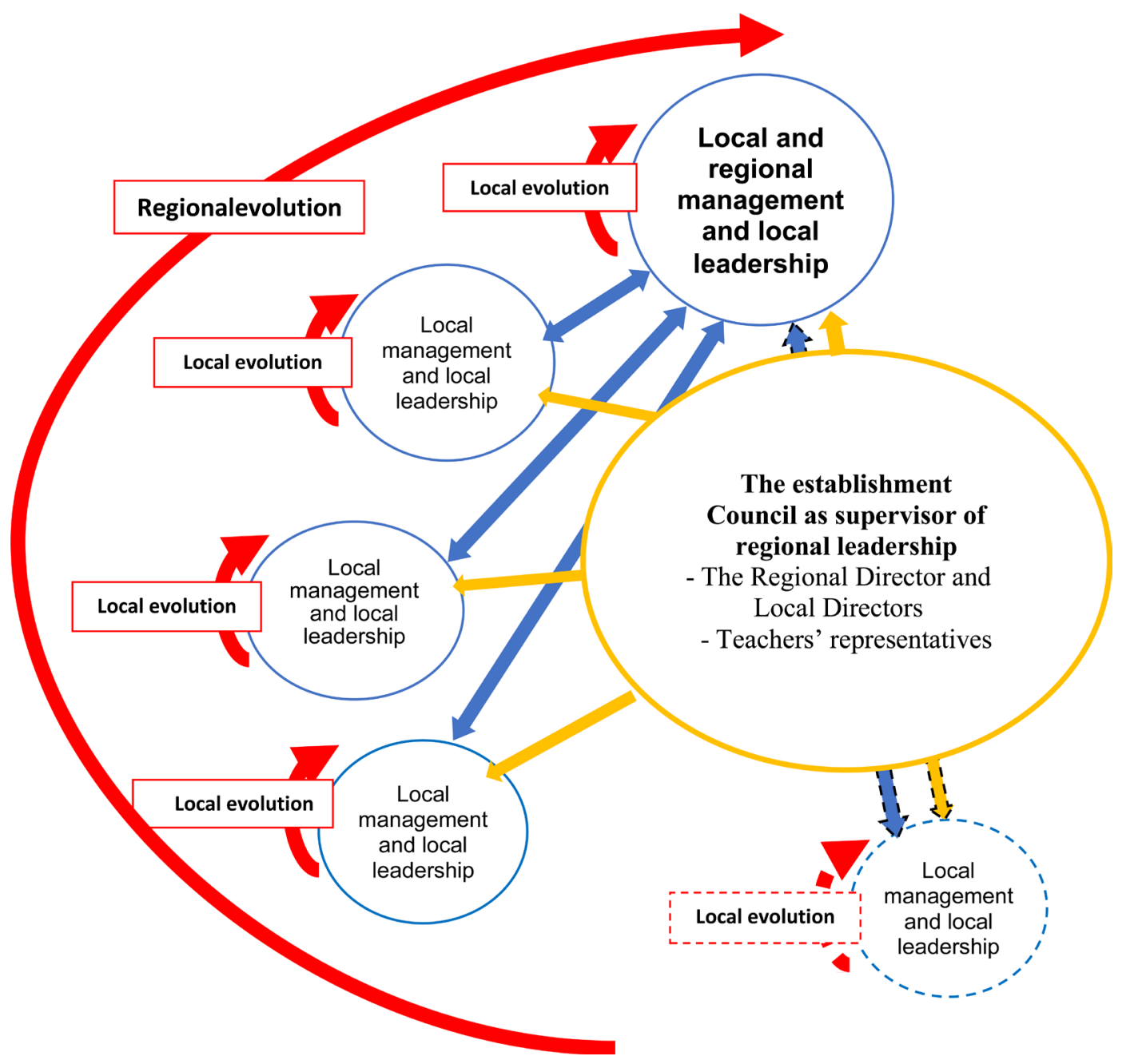

Figure 1. Architecture proposal for satellite educational leadership.

their structures-are subject, as regards the functioning of the Councils of their establishments, to the same framework law, in this case, Law 01.00, the main rules of power games between Management (or Dean's office for the Faculties) and Teachers are similar. Therefore, the clustered institutions can each develop their local educational leadership to participate in the development of a global satellite leadership that frames and regulates the evolution of "common action". This same configuration can be applied to any training organization with similar rules of power play in the supervision of its operation by the simultaneous cooperation of teachers and management.

\section{Research Characteristics}

\subsection{Final Result}

In terms of our work, we ended up with a form of leadership, which we called "satellite leadership", allowing each annex or provincial branch-of a Regional Center for Trades in Education and Training-to develop its local leadership, while evolving with the evolution of the regional leadership orbit. 


\subsection{Research Limitations}

We have set ourselves, as the main objective, in this investigative work, to know the state of play in terms of vision and values shared by the two main actors of educational leadership in a Regional Center for Trades of Education and training, in this case, management, and teachers. This is a starting point and a necessary, but not sufficient, condition for any educational leadership.

\subsection{Practical Implications}

The proposed new configuration of this satellite leadership would allow any structure, as a training establishment, grouping sub-structures, to develop a global educational leadership which frames and guides the local educational leaderships of each branch or annex forming part of the organization. regional education and training establishment. This approach goes hand in hand with the new orientations which attempt to deploy an integrated model of governance that combines central development giving more leeway to regional developments that frame local management flexibility.

\subsection{Values}

In this logic, the actors-managers and teachers-promoters of change aimed at improving management performance, teaching and student results, will have more opportunities to create positive change. And this, in a climate of managerial and educational competition where each branch or local annex tries to distinguish itself at the regional level.

\subsection{What Makes Our Research Unique?}

We believe that our research is unique in that we propose a satellite model of educational leadership based on local leaderships framed by regional leadership. This type of educational leadership takes into account, of course, the latest trends which take into account the emotional aspect of the actors in the exercise of their professional function. Knowing that the articulation between concentrated, distributed, transactional, or transformational leadership always remains negotiated according to the practices situated.

\section{Institutional Evaluation to Develop the Center Performance}

\subsection{Modeling of the Centre's Performance Management}

Whether the model recommended for an institutional evaluation of the Center is based on actors, spaces, or functions, the objective is to know the state of play in terms of performance. This knowledge, through an assessment using key performance indicators according to well-defined criteria, makes it possible to undertake corrective or improvement actions. To ensure that each staff member understands their role in the success of the students and the center, modeling the center by actors is appropriate. From this postulate, a definition of criteria concerning ac- 
tors such as managers, assistants, and teachers can be developed as mentioned in Table 1 below:

Table 1. Modeling of the performance management of the Center according to the actors

\begin{tabular}{|c|c|c|c|c|c|c|}
\hline \multirow[b]{2}{*}{ ACTOR } & \multirow[b]{2}{*}{ CRITERION } & \multirow[b]{2}{*}{ INDICATOR } & \multicolumn{4}{|c|}{ PERFORMANCE LEVEL } \\
\hline & & & No mastery & $\begin{array}{c}\text { Low } \\
\text { mastery }\end{array}$ & $\begin{array}{l}\text { Average } \\
\text { mastery }\end{array}$ & $\begin{array}{l}\text { Good } \\
\text { mastery }\end{array}$ \\
\hline \multirow{9}{*}{ MANAGER } & & Organized and up-to-date documents & & & & \\
\hline & Administrative management & The training system's control & & & & \\
\hline & & Activation of the Center Council & & & & \\
\hline & & Budget proposal & & & & \\
\hline & Financial management & Documented financial transactions & & & & \\
\hline & & Updated financial records & & & & \\
\hline & & Existence of educational partnerships & & & & \\
\hline & Partnerships & Socio-economic openness & & & & \\
\hline & & Existence of a communication plan & & & & \\
\hline \multirow{9}{*}{ TEACHER } & & Compliance with the training system & & & & \\
\hline & Teaching efficiency & Assessment of learning & & & & \\
\hline & & Teaching evaluation & & & & \\
\hline & & Attendance at Board meetings & & & & \\
\hline & $\begin{array}{l}\text { Involvement in the Council of } \\
\text { the Center }\end{array}$ & Participation in committees & & & & \\
\hline & & Monitoring of Board performance & & & & \\
\hline & & Involvement in scientific activities & & & & \\
\hline & $\begin{array}{l}\text { Involvement in the activities of } \\
\text { the Center }\end{array}$ & Involvement in cultural activities & & & & \\
\hline & & Involvement in social activities & & & & \\
\hline \multirow{9}{*}{ ASSISTANT } & & Clean training rooms & & & & \\
\hline & Hygiene & Clean spaces & & & & \\
\hline & & Clean sanitary & & & & \\
\hline & & Presence of green spaces & & & & \\
\hline & Ecology & Maintenance of green spaces & & & & \\
\hline & & Energy saving & & & & \\
\hline & & User safety & & & & \\
\hline & Monitoring & Video surveillance & & & & \\
\hline & & Center's heritage preservation & & & & \\
\hline
\end{tabular}

This grid will then serve as a dashboard or map visualizing the state of play in terms of the contribution of each actor in the development of the performance of the Center. Improvement interventions are maintained according to the priorities of the Center. The main common objective is the improvement of stu- 
dent performance.

\subsection{In Educational Leadership: How Can a Leader Fail?}

In educational leadership, a leader can fail by sliding into the transactional leadership model. Indeed, the successes achieved in the short term cannot last, and risk becoming destabilized once the common interest between management and teachers disappears for whatever reason. The sustainable alternative to any leadership must be based on institutional management. This management projects changes whose vision is shared by all stakeholders to improve their working conditions and aims to improve student performance. Once the practices are institutionalized, the departure of some people is not likely to destabilize the continuity of the educational leadership process.

\section{Conclusion}

By observing the evolution of the concept of educational leadership according to the characterization of its practices, we can see the continuous dynamics of its contextualization. Indeed, from its approach focused on the manager as a leader, this concept has evolved into the distributed approach on management, as a formal actor, and on teachers, as non-formal actors. This same approach has been situated, to the extent that it becomes focused on managers or teachers depending on the situation. With a little more hindsight allowing us to recognize other characteristics of any educational leadership, we have witnessed the emergence of an identification of the naturally and socially present emotional dimension (Samier \& Schmidt, 2009; Crawford, 2007; Piot \& Kelchtermans, 2014), during the exercise of any educational leadership, among principals as well as among teachers. This dimension made it possible to think of an integrated approach that must take into consideration, not only the affective side of the actors of educational leadership but also the interest of all the actors of the establishment in a systemic way (Pelletier, 2018). Since the target objective is to improve the performance of all stakeholders in the institution, and therefore that of the institution, that of the students cannot be the only priority. Indeed, without the development of educational scientific research and the reflective teaching and managerial practices of all stakeholders, isolated improvement efforts risk not being successful.

In the same systemic, integrated, and evolving logic, we conducted our study based on characterizing the leadership practiced jointly by the managers and teachers of a Regional Center for the Professions of Education and Training. Recalling that in Morocco, there are twelve centers and that each one is a group of similar local training centers for future teachers and executives of the pedagogical administration of the Ministry of National Education of Morocco. These future teachers and administrative executives will work together, by the same logic of educational leadership, to develop the performance of the schools to which they will be assigned. From this comes the importance of the challenge of 
successful innovative educational leadership.

By targeting the characterization of educational leadership within a Regional Centers for the Professions of Education and Training and more particularly about the construction of the Centre's commitments on a vision and values, practices have shown us that the Director, along with the Deputy Directors and certain teachers, practice a form of educational leadership converging towards what we have called satellite educational leadership. In this model of leadership, each Deputy Director, in the company of certain teachers from his establishment, practices a form of local leadership. This local leadership characterizes its establishment and advances at its own pace. This testifies to the persistence of several local leaderships to be taken into consideration to regulate the negotiated evolution of all the annexes and provincial branches of the same Regional Center, and this, by benefiting from the local potential and skills for the development of educational leadership. The pace of its development is supervised by the Council of the Regional Center where Management and Teachers share common working values allowing the same vision of the Center to be achieved at the regional level.

\section{Conflicts of Interest}

The authors declare no conflicts of interest regarding the publication of this paper.

\section{References}

Bass, B. M. (1998). Transformational Leadership: Industrial, Military, and Educational Impact. Mahwah: Lawrence Erlbaum.

Bruggencate, G., Luyten, H., Scheerens, J., \& Sleegers, P. (2012). Modeling the Influence of School Leaders on Student Achievement: How Can School Leaders Make a Difference? Educational Administration Quarterly, 48, 699-732. https://doi.org/10.1177/0013161X11436272

Burns, J. M. (1978). Leadership, New York, NY: Harper \& Row.

Campbell, R. F. (1981). The Professorship in Educational Administration-A Personal view. Educational Administration Quarterly, 17, 1-24. https://doi.org/10.1177/0013161X8101700102

Castillo, F. A., \& Hallinger, P. (2018). Systematic Review of Research on Educational Leadership and Management in Latin America, 1991-2017. Educational Management Administration \& Leadership, 46, 207-225. https://doi.org/10.1177/1741143217745882

Clarke, S., \& O’Donoghue, T. (2017). Educational Leadership and Context: A Rendering of an Inseparable Relationship. British Journal of Educational Studies, 65, 167-182. https://doi.org/10.1080/00071005.2016.1199772

Collarbone, P., \& Billingham, M. (1998). Leadership and Our Schools (Bulletin). London: Institute of Education.

Crawford, M. (2007). Rationality and Emotion in Primary School Leadership: An Exploration of Key Themes. Educational Review, 59, 87-98.

https://doi.org/10.1080/00131910600797155

Dumay, X. (2009). Origins and Consequences of Schools' Organizational Culture for 
Student Achievement. Educational Administration Quarterly, 45, 523-555. https://doi.org/10.1177/0013161X09335873

Dutercq, Y., Gather Thurler, M., \& Pelletier, G. (2015). Introduction. In Y. Dutercq, M. Gather Thurler, \& G. Pelletier (Eds.), Le Leadership éducatif: Entre défi et Fiction (pp. 7-19). Louvain-la-Neuve: Boeck Supérieur.

Flessa, J., Bramwell, D., Fernandez, M., \& Weinstein, J, (2017). School Leadership in Latin America 2000-2016. Educational Management Administration \& Leadership, 46, 182-206. https://doi.org/10.1177/1741143217717277

Garant, M., Letor, C., \& Bonami, M. (2010). Ch. 4: Leadership et Apprentissage Organisationnel. In L. Corriveau, (Ed.), Travailler Ensemble dans les Établissements Scolaires et de Formation: Processus, Stratégies, Paradoxes (pp. 63-77). Louvain-la-Neuve: Boeck Supérieur.

Greenfield, W. D. (1991). The Micropolitics of Leadership in an Urban Elementary School. In J. Blase (Ed.), The Politics of Life in Schools. Power, Conflict, and Cooperation (pp. 161-184). Newbury Park, CA: Sage.

Gronn, P. (2008). The Future of Distributed Leadership. Journal of Educational Administration, 46, 141-158. https://doi.org/10.1108/09578230810863235

Gronn, P., \& Hamilton, A. (2004). “A Bit More Life in the Leadership”: Co-Principalship as Distributed Leadership Practice. Leadership and Policy in Schools, 3, 3-35. https://doi.org/10.1076/lpos.3.1.3.27842

Gumus, S., Bellibas, M. S., Esen, M., \& Gumus, E. (2018). A Systematic Review of Studies on Leadership Models in Educational Research from 1980 to 2014. Educational Management Administration \& Leadership, 46, 25-48. https://doi.org/10.1177/1741143216659296

Hallinger, P. (2011a). A Review of Three Decades of Doctoral Studies Using the Principal Instructional Management Rating Scale: A Lens on Methodological Progress in Educational Leadership. Educational Administration Quarterly, 47, 271-306. https://doi.org/10.1177/0013161X10383412

Hallinger, P. (2011b). Leadership for Learning: Lessons from 40 Years of Empirical Research. Journal of Educational Administration, 49, 125-142. https://doi.org/10.1108/09578231111116699

Hallinger, P. (2014). Reviewing Reviews of Research in Educational Leadership: An Empirical Assessment. Educational Administration Quarterly, 50, 539-576. https://doi.org/10.1177/0013161X13506594

Hallinger, P. (2018a). Bringing Context Out of the Shadows of Leadership. Educational Management Administration \& Leadership, 46, 5-24. https://doi.org/10.1177/1741143216670652

Hallinger, P. (2018b). Surfacing a Hidden Literature: A Systematic Review of Research on Educational Leadership and Management in Africa. Educational Management Administration \& Leadership, 46, 362-384. https://doi.org/10.1177/1741143217694895

Hallinger, P. (2019). Science Mapping the Knowledge Base on Educational Leadership and Management from the Emerging Regions of Asia, Africa and Latin America, 1965-2018. Educational Management Administration \& Leadership, 48, 209-230. https://doi.org/10.1177/1741143218822772

Hallinger, P., \& Bryant, D. (2013). Mapping the Terrain of Educational Leadership and Management in East Asia. Journal of Educational Administration, 51, 618-637. https://doi.org/10.1108/JEA-05-2012-0066

Hallinger, P., \& Chen, J.J. (2015). Review of Research on Educational Leadership and Management in Asia: A Comparative Analysis of Research Topics and Methods, 
1995-2012. Educational Management Administration \& Leadership, 43, 5-27. https://doi.org/10.1177/1741143214535744

Hallinger, P., \& Heck, R. H. (1996). Reassessing the Principal's Role in School Effectiveness: A Review of Empirical Research, 1980-1995. Educational Administration Quarterly, 32, 5-44. https://doi.org/10.1177/0013161X96032001002

Hallinger, P., \& Heck, R. H. (2010). Leadership for Learning: Does Collaborative Leadership Make a Difference in School Improvement? Educational Management Administration and Leadership, 38, 654-678. https://doi.org/10.1177/1741143210379060

Hallinger, P., \& Kovačević, J. (2019). A Bibliometric Review of Research on Educational Administration: Science Mapping the Literature, 1960 to 2018. Review of Educational Research, 89, 335-369. https://doi.org/10.3102/0034654319830380

Hargreaves, A., \& Fullan, M. (2012). Professional Capital: Transforming Teaching in Every School. New York, NY: Teachers College Press.

Harris, A. (2004). Distributed Leadership and School Improvement: Leading or Misleading? Educational Management Administration \& Leadership, 32, 11-24. https://doi.org/10.1177/1741143204039297

Hooper, M. A., \& Bernhardt, V. L. (2016). Creating Capacity for Learning and Equity in Schools: Instructional, Adaptive, and Transformational Leadership. New York, NY: Routledge. https://doi.org/10.4324/9781315668697

Hoy, W., \& Miskel, C. (2012). Educational Administration: Theory, Research, and Practice (9th ed.). New York, NY: McGraw-Hill Higher Education.

James, M. K., \& Barry, Z. P. (2019). Leadership in Higher Education: Practices That Make a Difference. Oakland, CA: Berrett-Koehler Publishers, Inc.

Leithwood, K., \& Mascall, B. (2008). Collective Leadership Effects on Student Achievement. Educational Administration Quarterly, 44, 529-561.

https://doi.org/10.1177/0013161X08321221

Miller, P. W. (2019). “Tackling” Race Inequality in School Leadership: Positive Actions in BAME Teacher Progression-Evidence from Three English Schools. Educational Management Administration and Leadership, 48, 986-1006.

https://doi.org/10.1177/1741143219873098

Northouse, P. G. (2019). Leadership: Theory \& Practice. Thousand Oaks, CA: SAGE.

Oplatka, I., \& Arar, K. H. (2017). The Research on Educational Leadership and Management in the Arab World Since the 1990s: A Systematic Review. Review of Education, 5, 267-307.

Pelletier, G. (2017). Devenir Dirigeant en Éducation: Défi d'Identité, défi de Savoir d'Action. Revue Enseignement et Recherche en Administration de l'Éducation, 1, 49-63.

Pelletier, G. (2018). Le Leadership Éducatif et la Gouvernance des Systèmes Éducatifs: Un Regard Pluriel. Éducation et Francophonie, 46, 1-10. https://doi.org/10.7202/1047132ar

Perrenoud, O., \& Progin, L. (2018). Le Leadership: Un Processus Distribué au Sein des Établissements Scolaires? Le cas de la Suisse Francophone, Education et Francophonie, 46, 33-49. https://doi.org/10.7202/1047134ar

Piot, L., \& Kelchtermans, G. (2014). Le Leadership Dans les Organisations Scolaires Contemporaines: Leçons Tirées de la Revue de la Littérature Anglo-Saxonne. In M. Garant (ed.), Encadrement et Leadership: Nouvelles Pratiques en Éducation et Formation (pp. 21-37). Louvain-la-Neuve: Boeck Supérieur.

https://doi.org/10.3917/dbu.letor.2014.01.0021 
Rey, C., \& Cardona, P. (2015). Liderazgo en la Dirección por Misiones (Working Paper 10-2015). Barcelona: Publicaciones UIC.

Ribbins, P., \& Gunter, H. (2002). Mapping Leadership Studies in Education: Towards a Typology of Knowledge Domains. Educational Management Administration \& Leadership, 30, 359-385. https://doi.org/10.1177/0263211X020304002

Riffel, J. A. (1986). The Study of Educational Administration: A Developmental Point of View. Journal of Educational Administration, 24, 152-172. https://doi.org/10.1108/eb009914

Rowan, B. (1995). Learning, Teaching, and Educational Administration: Toward a Research Agenda. Educational Administration Quarterly, 31, 344-354. https://doi.org/10.1177/0013161X95031003002

Samier, E. A., \& Schmidt, M. (2009). Emotional Dimensions of Educational Administration and Leadership. London: Routledge. https://doi.org/10.4324/9780203870808

Scheerens, J. (2012). School Leadership Effects Revisited. Dordrecht: Springer. https://doi.org/10.1007/978-94-007-2768-7

Tintoré, M. (2019). Introducing a Model of Transformational Pro-Social Leadership. Journal of Leadership Studies, 13, 15-34.

Vuori, J. (2019). Distributed Leadership in the Construction of a New Higher Education Campus and Community. Educational Management Administration \& Leadership, 47, 224-240. https://doi.org/10.1177/1741143217725322

Walker, A., \& Hallinger, P. (2015). A Synthesis of Reviews of Research on Principal Leadership in East Asia. Journal of Educational Administration, 53, 554-570. https://doi.org/10.1108/JEA-05-2015-0038

Wang, Y., Bowers, A. J., \& Fikis, D. J. (2017). Automated Text Data Mining Analysis of Five Decades of Educational Leadership Research Literature: Probabilistic Topic Modeling of EAQ Articles from 1965 to 2014. Educational Administration Quarterly, 53, 289-323. https://doi.org/10.1177/0013161X16660585

Witziers, B., Bosker, R. J., \& Kruger, M. L. (2003). Educational Leadership and Student Achievement: The Elusive Search for an Association. Educational Administration Quarterly, 39, 398-425. https://doi.org/10.1177/0013161X03253411

Young, M. D., Winn, K. M., \& Reedy, M. A. (2017). The Every Student Succeeds Act: Strengthening the Focus on Educational Leadership. Educational Administration Quarterly, 53, 705-726. https://doi.org/10.1177/0013161X17735871

Yukl, G. (2006). Leadership in Organizations. Upper Saddle River, NJ: Prentice Hall.

Zulkifly, N. A., Ismail, I. A., \& Asimiran, S. (2020). Collegial and Distributed Leadership: Two Sides of the Same Coin? International Journal of Leadership in Education. https://doi.org/10.1080/13603124.2020.1804623 